\title{
X-linked Hydrocephalus
}

\author{
MICHAEL W. SHANNON and HENRY L. NADLER* \\ From the Department of Pediatrics, Northwestern University School of Medicine, and the Genetic Clinic, \\ Children's Memorial Hospital, Illinois, Chicago, U.S.A.
}

Since the original description of a sex-linked mode of inheritance in congenital hydrocephalus (Bickers and Adams, 1949), subsequent reports have been published presenting additional families in which this inheritance pattern appeared to be present. Bamatter (1949) described a family in which the mother had delivered 2 hydrocephalic males and 3 normal females. Zimmer (1952) reviewed a family with 3 stillborn hydrocephalic males, while Borle (1953) reported 3 hydrocephalic brothers in one family. Gellman (1959) presented twin hydrocephalic brothers. Edwards, Norman, and Roberts (1961) and Edwards (1961), described 4 families with histories of hydrocephalus, one with 15 affected males. Needleman and Root (1963) reported 2 families, one of which revealed hydrocephalic male offspring from 2 different fathers. Warren, Lu, and Ziering (1963) reviewed a family with 3 known hydrocephalic brothers and 2 additional probable hydrocephalic males. AbdulKarin, Iliya, and Iskandar (1964) reported 3 consecutive stillborn hydrocephalics from a single mother. Williamson (1965) discussed one family with 2 hydrocephalic brothers and another family with a male hydrocephalic, whose mother had one hydrocephalic brother and another brother with probable hydrocephalus. An additional 2 families were described by Walker (1960), one with 4 hydrocephalic males.

The evidence that the families reported demonstrate an X-linked recessive inheritance pattern was as follows: hydrocephalus occurred only in males; all females were normal; the condition was transmitted from one generation to another by a carrier female; and finally, the reports of Edwards et al. (1961), Needleman and Root (1963), and Walker (1960), in which a woman had hydrocephalic male offspring from two different fathers. The purpose of this paper is to present a family with $\mathrm{X}$-linked

Received January 22, 1968.

$\star$ Reprint requests to Dr. Nadler at Children's Memorial Hospital, 2300 Children's Plaza, Chicago, Illinois 60614, U.S.A. inherited hydrocephalus in which 4 males were affected in 2 generations. The importance of distinguishing this group of patients from non-familial hydrocephalus and the relation of genetic counselling will be discussed.

\section{Case Report}

The propositus (Pedigree III.2) presented at Children's Memorial Hospital at 8 days of age with an enlarged head and probable congenital megacolon. He was the product of a full-term uncomplicated pregnancy of a gravida 2 para 2, 25-year-old woman whose previous child, a female infant with 18-trisomy, died at 17 months of age. Delivery was complicated by the large head, and forceps were necessary. Head circumference at birth was $41.0 \mathrm{~cm}$., weight $3643 \mathrm{~g}$., chest circumference $31.5 \mathrm{~cm}$., and anterior and posterior fontanelles bot measured $3 \times 4 \mathrm{~cm}$. The head did not transilluminate and skull $x$-rays showed no calcifications.

The head circumference on the fifth day after admission was $41.5 \mathrm{~cm}$., and ventriculograms revealed symmetrical dilatation of both lateral ventricles, normal third ventricle, and no visualization of air beyond the proximal portion of the aqueduct of Sylvius, the postoperative diagnosis being stenosis of the aqueduct. A ventriculo-atrial shunt was performed on the 21 st hospital day, at which time the head circumference was $42.5 \mathrm{~cm}$. Subsequent pneumoencephalograms and Pantopaque studies further substantiated the diagnosis of a blockage of the aqueduct of Sylvius at the junction of the lower two-thirds with the upper two-thirds of the aqueduct.

Chromosome studies on the propositus and his mother yielded the following results: propositus 46XY, mother 46XX, with no chromosomal abnormalities observed in either case.

A male maternal cousin (Pedigree III.4) of the propositus was brought to Children's Memorial Hospital at 3 years of age with a previous diagnosis of hydrocephalus and mental retardation. Physical examination on admission revealed a head circumference of $55 \mathrm{~cm}$. An operative pneumoventriculogram and Pantopaque ventriculogram demonstrated dilatation of the lateral ventricles, an enlarged third ventricle, and aqueductal stenosis. A III-IV ventriculo-ventriculostomy was carried out at a later date. Two male sibs of this cousin are normal. 


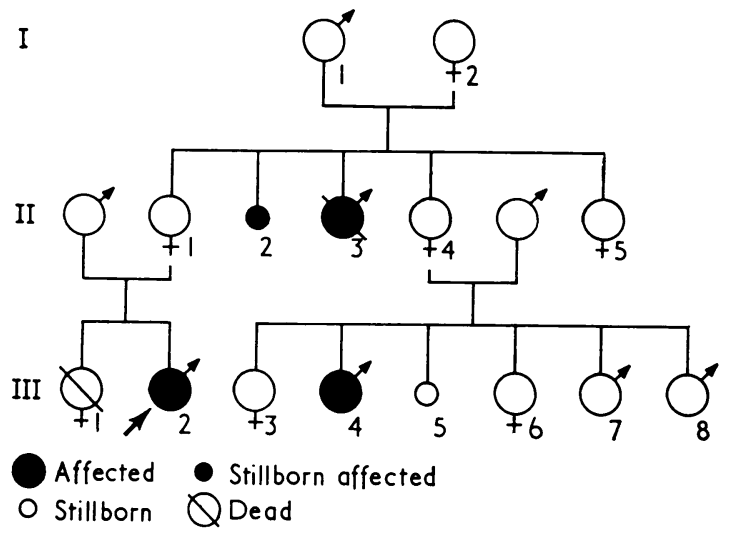

FIG. Pedigree of the family with X-linked hydrocephalus. There are 4 affected members (darkened symbols), one of whom was an affected stillborn male (II.2).

Two maternal uncles of the propositus were also known to be hydrocephalic, one a stillborn (Pedigree II.2), and the other (Pedigree II.3) dying at the age of 11 : in this case, an aqueductal stenosis was found at necropsy. Further investigation of the family history revealed no other instances of hydrocephalus.

\section{Discussion}

Many surveys have been carried out in recent years to determine the incidence of hydrocephalus and other central nervous system abnormalities (Table). The incidence of congenital hydrocephalus, not associated with myelomeningocele, varies from 0.22 per thousand live births to 1.8 per thousand total births. Carter (1963) has estimated the incidence in Europe to be approximately 0.5 per

TABLE

STUDIES OF MAJOR CONGENITAL MALFORMATIONS

\begin{tabular}{|c|c|c|c|}
\hline Author & Location of Study & $\begin{array}{c}\text { No. } \\
\text { of } \\
\text { Cases }\end{array}$ & $\begin{array}{c}\text { Incidence of } \\
\text { Congenital } \\
\text { Hydrocephalus } \\
\text { (per } 1000 \text { total } \\
\text { births) }\end{array}$ \\
\hline $\begin{array}{l}\text { Williamson (1965) } \\
\text { Wallace, } \\
\text { Baumgartner, } \\
\text { and Rich (1953) }\end{array}$ & $\begin{array}{l}\text { Southampton } \\
\text { New York }\end{array}$ & $\begin{array}{r}14,907 \\
1501\end{array}$ & $\begin{array}{l}0.90 \\
0.22 \text { 太 }\end{array}$ \\
\hline $\begin{array}{l}\text { Book (1951) } \\
\text { McIntosh et al. } \\
\text { (1954) }\end{array}$ & $\begin{array}{l}\text { Sweden } \\
\text { New York City }\end{array}$ & $\begin{array}{r}44,109 \\
5739\end{array}$ & $\begin{array}{l}1.00 \\
0.90 t\end{array}$ \\
\hline $\begin{array}{l}\text { Neel (1958) } \\
\text { Pleydell (1960) } \\
\text { McKeown and } \\
\text { Record (1960) }\end{array}$ & $\begin{array}{l}\text { Japan } \\
\text { Northamptonshire } \\
\text { Birmingham }\end{array}$ & $\begin{array}{l}64,569 \\
60,890 \\
56,760\end{array}$ & $\begin{array}{l}0 \cdot 30 \\
0 \cdot 60^{\star} \\
1 \cdot 80\end{array}$ \\
\hline McDonald (1961) & $\begin{array}{l}\text { Watford and St. } \\
\text { Albans }\end{array}$ & 3179 & $1 \cdot 60$ \\
\hline$\underset{(1961)}{\text { Simpkiss and Lowe }}$ & Kampala & 2068 & $1 \cdot 50$ \\
\hline
\end{tabular}

^ Per thousand live births. thousand births. It appears that the vast majority of cases of hydrocephalus are not primarily of genetic origin. If one combines the studies of Penrose (1960), McKeown and Record (1960), and MacMahon, Pugh, and Ingalls (1953), in which sibs of a propositus with hydrocephalus were studied, only one hydrocephalic infant was found in the 200 cases studied. In addition, analysis of the data of Record (1959, personal communication by Edwards et al. (1961)), showed no affected male sib of 50 male propositi studied.

The true incidence of aqueductal stenosis is not known, but among 44 necropsies of cases with infantile hydrocephalus, Elvidge (1966) found 30\% with aqueductal stenosis. It is of interest that in our cases as well as in 5 others (Bickers and Adams, 1949; Edwards et al., 1961; Needleman and Root, 1963; Warren et al., 1963) previously studied, the pathological lesion producing the hydrocephalus was aqueductal stenosis.

Though estimates of the incidence of X-linked hydrocephalus are about $2 \%$ (Brit. med.F., 1962) of all cases of uncomplicated hydrocephalus, every effort should be made to recognize this group of patients. While the over-all recurrence risk appears to be of the order of 0.5 to $1 \%$, in these X-linked cases the recurrence risk will usually be higher. Where the mother is known, from the family history, to be a carrier, it will be $50 \%$ for later brothers, and though none of the daughters will be affected $50 \%$ will in turn be carriers. Since there is no way to recognize the carrier state, one should exercise care in counselling parents of hydrocephalic offspring. Probably the greatest caution should be exercised when aqueductal stenosis is found in a male propositus.

\section{Summary}

A family showing the syndrome of $\mathrm{X}$-linked inherited hydrocephalus with 4 affected members in 2 generations is presented. The combined incidence of all forms of uncomplicated congenital hydrocephalus is reviewed and compared with the incidence to be expected in the X-linked form. The relevance of these figures to genetic counselling is discussed.

The authors wish to thank Dr. Michael Jerva for allowing them to study his patient, and Regina Kavaliunas for help in interviewing the family.

Supported in part by grants from the U.S. Public Health Service (1-S01-FR-5370-04).

\section{REFERENCES}

Abdul-Karin, R., Iliya, F., and Iskandar, G. (1964). Consecutive hydrocephalus: Report of 2 cases. Obstet. and Gynec., 24, 376. 
Bamatter, F. (1949). Acquisitions récentes concernant les hydrocéphalies inflammatoires chez l'enfant. Travail d'habilitation de la faculté de Medicine de Genève (dactylographie) 87. (Quoted by Edwards and by Borle.)

Bickers, D. S., and Adtins, R. D. (1949). Hereditary stenosis of the aqueduct of Sylvius as a cause of congenital hydrocephalus. Brain, 72, 246.

Book, J. A. (1951). The incidence of congenital diseases and defects in a South Swedish population. Acta genet (Basel), 2, 289.

Borle, A. (1953). Sur l'étiologie de l'hydrocéphalie congénitale. A propos d'un case d'hydrocéphalie concordante chez des jumeaux univitellins. F. Génét. hum., 2, 157.

Brit. med. F. (1962). Editorial. Sex-linked hydrocephalus with severe mental defect. $1,168$.

Carter, C. O. (1963). Incidence and aetiology (of congenital malformation in childhood). In Congenital Abnormalities in Infancy, p. 1. Ed. by A. P. Norman. Blackwell Scientific Publications, Oxford

Edwards, J. H. (1961). The syndrome of sex-linked hydrocephalus. Arch. Dis. Childh, 36, 486.

- Norman, R. M., and Roberts, J. M. (1961). Sex-linked hydrocephalus: Report of a family with 15 affected members. ibid., 36, 481.

Elvidge, A. R. (1966). Treatment of obstructive lesions of the aqueduct of Sylvius and the fourth ventricle by interventriculostomy. f. Neurosurg., 24, 11.

Gellman, V. (1959). Congenital hydrocephalus in monovular twins. Arch. Dis. Childh., 34, 274.

McDonald, A. D. (1961). Matronal health in early pregnancy and congenital defect; final report on a prospective inquiry. Brit. $\mathcal{F}$. prev. soc. Med., 15, 154.

McIntosh, R., Merritt, K. K., Richards, M. R., Samuels, M. H., and Bellows, M. T. (1954). The incidence of congenital malformations: A study of 5,964 pregnancies. Pediatrics, 14, 505.

McKeown, T., and Record, R. G. (1960). Malformations in a popu- lation observed for five years after birth. In Ciba Foundation Symposium on Congenital Malformations, p. 2 Ed. by G. E. W. Wolstenholme and C. M. O'Connor. Churchill, London.

MacMahon, B., Pugh, T. F., and Ingalls, T. H. (1953). Anencephalus, spina bifida, and hydrocephalus: Incidence related to sex, race, and season of birth, and incidence in siblings. Brit. $\mathcal{F}$. prev. soc. Med., 7, 211.

Needleman, H. L., and Root, A. W. (1963). Sex-linked hydrocephalus: Report of two families, with chromosomal study of two cases. Pediatrics, 31, 396.

Neel, J. V. (1958). A study of major congenital defects in Japanese infants. Amer. F. hum. Genet., 10, 398.

Penrose, L. S. (1960). Genetic causes of malformations. In Ciba Foundation Symposium on Congenital Malformations, p. 22. Ed. by G. E. W. Wolstenholme and C. M. O'Connor. Churchill, London.

Pleydell, M. J. (1960). Anencephaly and other congenital abnormalities. An epidemiological study in Northamptonshire. Brit. med. F., 1, 309.

Simpkiss, M., and Lowe, A. (1961). Congenital abnormalities in the African newborn. Arch. Dis. Childh., 36, 404.

Walker, J. (1960). Discussion, genetical causes of malformations and the search for their origins. In Ciba Foundation Symposium on Congenital Malformations, p. 30. Ed. by G. E. W. Wolstenholme and C. M. O'Connor. Churchill, London.

Wallace, H. M., Baumgartner, L., and Rich, H. (1953). Congenital malformations and birth injuries in New York City. Pediatrics, 12, 525 .

Warren, M. C., Lu, A. T., and Ziering, W. H. (1963). Sex-linked hydrocephalus with aqueductal stenosis. $\mathcal{F}$. Pediat., 63, 1104.

Williamson, E. M. (1965). Incidence and family aggregation of major congenital malformations of central nervous system. $\mathcal{f}$. med. Genet., 2, 161.

Zimmer, K. (1952). Uber familiäres Auftreten von Hydrozephalus. Geburtsh. u. Frauenheilk., 12, 447. 